\title{
An Inventory of Ferns (Pteridophyta) in Plantation PTPN Nusantara 3 Rantau Prapat District Labuhanbatu
}

\author{
Jahot Tua Situmorang ${ }^{1}$, Rosmidah Hasibuan ${ }^{2}$ \\ ${ }^{1,2}$ Faculty of Teacher training and Education Science, Universitas Labuhanbatu, Indonesia \\ rosmidahhasibuan01@gmail.com
}

\begin{abstract}
PTPN Nusantara 3 is one of the Companies engaged in the field of Rubber plantations and Palm oil that has a wide 9.150,80 ha. Rubber plantation PTPN Nusantara 3 Rantau Prapat is one area that there are many ferns. Ferns (Pteridophyta) are most commonly found in the area of rubber Plantation PTPN Nusantara 3 Rantau Prapat District Labuhanbatu is a family Dryopteridaceaese lot of 6 species, namely Nephrolepisbiserrata, Nephrolepiscor difolia, Nephrolepi sexaltata, Nephrolepissp, Ploecnemia irregularis and Stenochlaenae palustris. Based on the results of research conducted by researchers on 03-May-11 May 2021 in the rubber Plantation PTPN Nusantara 3 Rantau Prapat District Labuhanbatu, researchers found 7 famili ferns (Pteridophyta), namely Aspleniaceae, Blechnaceae, Davalliaceae, Dryopteridaceae, Gleicheniaceae, Lycopodiaceae, Polypodiaceae, with 17 species of ferns (Pteridophyta). Abiotic factors that can affect the growth of the nail is different because according to his needs, namely air temperature $29 \mathrm{C}$-32 C while the soil moisture that is up 7.9\%-69\% and the $\mathrm{pH}$ of the soil ranged from 8.00 8,90.
\end{abstract}

Keywords

pteridophyta; PTPN nusantara 3; nephroleusanpis biserrata

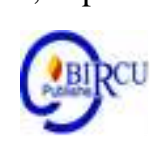

\section{Introduction}

Agricultural land is increasingly narrow due to the shifting of the function of agricultural land into industrial areas, so that hydroponic cultivation is considered appropriate to utilize available land because this cultivation system does not require soil media. The hydroponic system uses a variety of planting media other than soil, among others, with media such as fuel husk, husk, sand, zeolite, rockwoll, peat (peat moss) and coconut husk powder (Zailani et al, 2019).

Plants are one of the groups of living creatures-celled many that are on the face of the earth. Herbs have body parts that can be differentiated into roots, stems, and leaves. The plant has a size that is very diverse, ranging from small-sized that do not have wood to large trees and very tall that he can reach hundreds of years. Types of the plants are edible and there are those who can not be eaten because it is poisonous or barbed (Fitriana, 2008).

Asbar (2004) explains that ferns can be grown in different habitats. Based on the place of his life, the ferns found widespread started to tropical regions near the north and south poles. Starting from primary forest, secondary forest, open nature, the lowlands to the highlands, the environment is humid, damp, shady, garden plants, roadside nails can be encountered.

Ferns can be divided into two main parts: the organs of vegetative consisting of roots, stems, rhizomes, and leaves. While the generative organs consist of spores, sporangium, anteridium, and archegonium. Sporangium ferns generally located at the bottom of the leaves sertamembentuk cluster of black or brown. Cluster sporangium is known as the sorus. Layout sorus against the bones of the leaf is a trait that is very important in the classification of ferns. 
According to Tjitrosoepomo (1994) the division Pteridophyta can be grouped into four classes, namely Psilophytinae, Lycopodiinae,Equisetinae and Filiciane; and according to Steennis (1988), plants ferns can be divided into 11 families, namely Salviniceae, Marsileaceae, Equicetaceae, Selagillaceae, Lycopodiaceae, Ophiglossaceae, Schizaeaceae, Gleicheniaceae, Cyatheaceae, Ceratopteridaceae, and Polypodiaceae. Ferns quite a lot, there are several types of ferns, one of that Asplenium nidus be used as an ornamental plant, and also dapatdijumpai ferns (Pteridophyta) are grown by a tree, on the ground and along the roadside. One of the places that serve as the research location ferns (Pteridophyta), namely in the rubber Plantation PTPN Nusantara 3 Rantau Prapat District Labuhanbatu is one of the Companies engaged in the Rubber plantation area that has 9.150,80 ha. Rubber plantation PTPN Nusantara 3 Rantau Prapat District Labuhanbatu is one area that there are many ferns. Based on the results of observasidi rubber Plantation PTPN Nusantara 3 Rantau Prapat District Labuhanbatu that ferns are quite many. The results obtained through the observation is that there are several types of ferns, one of that Aspleniumnidus in use as ornamental plants can be encountered in the soil and along the roadside. The results of the observations made in the rubber Plantation PTPN Nusantara 3 Rantau Prapat District District there different types of plants ferns which has not been identified and there has been no previous research to do research about the types of ferns (Pteridophyta) in the rubber Plantation PTPN Nusantara 3 Rantau Prapat District Labuhanbatu.

\section{Research Methods}

\subsection{Tools and Materials}

The tool used in this research is as follows: Book referencing the ferns (Pteridophyta), camera,stationery, knives, scissors, paper, carton, label paper, tape, bottle of spray, Soil tester, Thermometer, Hygrometer, plastic, plastic bening, thread, needle, water, petalokasi, alcohol $96 \%$ and all the ferns (Pteridophyta).

\subsection{Research Procedure}

The procedure of this research is prefixed with the activities of observation aimed to obtain preliminary data on the ferns (Pteridophyta) in Plantation rubber PTPN Nusantara 3 Region Prapat with the condition of the location will be made the object of research as well as see some of its habitat. Next do the sampling and manufacturing herbarium dry namely: the ferns (Pteridophyta) are taken consist of roots, stems, leaves and spores in the collection. Then put it in a bag plastic white spray it with alcohol $96 \%$ and a label that contains a description of a number of species, the name of the local location and the name of the ferns (Pteridophyta). The plants in place on the paper and in spray of alcohol $96 \%$ and then at closing with the paper with isolation. Herbarium dry, ferns (Pteridophyta) aerated glass enclosure allows the sprayed again with the use of alcohol $90 \%$. The Herbarium has been keringlangsung moved up the carton thick, then in isolation and in sewing, as well as give evidence later in identification (Purnawatidkk, 2014). Next is the measure factor abiotic covering measure the temperature of air using the tool the form of a Thermometer, to measure soil moisture using a Hygrometer, and measure the $\mathrm{pH}$ of the soil using a tool soil tester. 


\subsection{Analytica Data}

The research is based on the study of the kind of tumble tumble that is thought to be on the observation line. The research analysed data collected from the breed, the abuja and the descendants of paku (Pteridophyta), in identification with the authors Of the panduan Van Steenenis book (2013), Rina Fitriana (2008), The book "Oky Saktyowati (2016), Wiwik Endang Mardiastutik (2013) Siti Sutarmi Tjitrosomo (2010) and Nyoman Wijaya (2014).

\section{Results and Discussion}

Based on the results of research conducted by researchers on 03-May-11 May 2021 in the rubber Plantation PTPN Nusantara 3 Rantau Prapat District Labuhanbatu, researchers found 7 famili tumbuhan paku (Pteridophyta), namely Aspleniaceae, Blechnaceae, Davalliaceae, Dryopteridaceae, Gleicheniaceae, Lycopodiaceae, Polypodiaceae, with 17 species of ferns (Pteridophyta). Abiotic factors that can affect the growth of the nail is different because according to his needs, namely air temperature $29 \mathrm{C}-32 \mathrm{C}$ while the soil moisture that is up 7.9\%-69\% and the $\mathrm{Ph}$ of the soil ranged from $8.008,90$.

Based on the results of observations, it is known that the species of ferns (Pteridophyta) are found in the rubber Plantation of PT Nusantara 3 District Labuhanbatu most are not utilized, there is one plant spikes are consumed by people as a food ingredient that is Diplazium esculantum and is in use as ornamental plants, namely Aspleniumnidus.

Ferns (Pteridophyta) are most commonly found in the area of rubber Plantation PTPN Nusantara 3 Rantau Prapat District Labuhanbatu is a family Dryopteridaceae as many as 6 species, namely Nephrolepisbi serrata, Nephrolepis cordifolia, Nephrolepi sexaltata, Nephrolepis sp., Ploecnemiairregularis and Stenochlaenae palustris. The family belonged to the type of nails terrestrial. Habitat in moist place with the root of the shaped fibers, the stem is green and slightly hairy, high reach $150 \mathrm{~cm}$. Leaf-shaped compound with a width of $45 \mathrm{~cm}$, the length and width of the kids leaves $25 \mathrm{~cm}$ and $3 \mathrm{~cm}$. In one stalk, usually leaves the numbered leaves 46 strands and the child leaves numbered 62 strands. On the surface of the upper leaves dark green and on the lower surface light green. While the young red leaves in the colours of the threads of delicate silvery. Textured leaves rather hard with a square shape. Sorus is located on the surface of the leaf (Cherry, et al., 2014).

Nephrolepis biserrata live on the soil $\mathrm{pH}$ of 7.9 soil moisture of $10 \%$ and the air temperature 32Chidup at high ambient temperature (Permana, 2017). Nephrolepisbi serrata live on the soil $\mathrm{pH} 4,2-4,4$ acidic while the humidity soil 7,2-9\% (Permana 2017). Nephrolepiscor in folia live on the soil $\mathrm{pH} 7.08$ to soil moisture $9 \%$ and the air temperature is 33C. According to riastuti has et al (2018:67) Nephrolepis cordifolia life on the ambient temperature ranges between $28-31 \mathrm{C}$ which means the temperature is relatively normal for the growth of the nails and the $\mathrm{pH}$ of the soil was 6.18 which means sour. According to Permana (2017) soil moisture at $8.9 \%-9 \%$.Nephrolepis exaltata live on the soil pH 7.08 to soil moisture 23\% and suhuudara 32C. According to riastuti has et al (2018) Nephrolepisexaltata life on the ambient temperature ranges antara28C-31C which means the temperature is relatively normal for the growth of the nails and the $\mathrm{pH}$ of the soil was 6.18 which means sour. According to Sari (2017) live on the soil moisture 1-2,5.

Neprolepis sp live on the soil $\mathrm{pH} 7.08$ to soil moisture $15 \%$ and the air temperature is 31C. According to the Darma et al (2018:43) Nephrolepis sp live on the ambient temperature ranges between $20,46 \mathrm{C}$, soil $\mathrm{pH}$ of $6.0-\mathrm{K}$ and soil moisture $29,12 \%$. Ploecnemia irregularis life on the $\mathrm{pH}$ of the soil 7,09 while the environment temperature is $32 \mathrm{C}$ and the soil moisture $19 \%$. 
According to the Darma et al (2018) Ploecnemia irregularis life on the ambient temperature ranges between $28-31 \mathrm{C}$ which means the temperature is relatively normal for the growth of the nails, the $\mathrm{pH}$ of the soil 6,16 which means sour. According to Sari (2017) Ploecnemia irregularis live on the soil moisture of $1-2 \%$. Stenochlaenae palustris life at $\mathrm{pH}$ tanah7,08, while according to riastuti has et al (2018) the temperature of the environment 31C which means the temperature is relatively normal for the growth of the nail and the soil moisture of $12 \%$. According to Ridianingsih et al (2017) Stenochlaenae palustris live on the soil $\mathrm{pH}$ of 6.4 to 6.5 , while the soil moisture of $20 \%$.

Family Polypodiaceae also found as many as 4 species namely Diplazium esculentum, Drymoglossum piloselloides, Drynaria quercifolia, and Phymatosorus scolopendria. Diplazium esculentum life on the $\mathrm{pH}$ of the soil that is 7,09 soil moisture $68 \%$ and the ambient temperature 32C. According to Syafrudin et al (2016) Diplazium esculentum life at a temperature of $28 \mathrm{C}-31 \mathrm{C}$ which means the temperature is relatively normal. According to Kurniawati et al (2016) Diplazium esculentum live on the soil $\mathrm{pH}$ of 7.5, while the soil moisture of $30 \%-40 \%$. Drymoglossum piloselloides life on the $\mathrm{pH}$ of the soil that is 7.08 to while soil moisture 8\% and According to Apriyanti et al (2017) ambient temperature 32C which means the temperature is relatively normal for the growth of nails. According to Imaniar et al (2017) Drymoglossum piloselloides live on the soil $\mathrm{pH}$ 6,2-6,7 while the soil moisture 47,53. Drynaria quercifolia life on the $\mathrm{pH}$ of the soil 7,09 soil moisture of $12 \%$, the ambient temperature is 32C. According to Permana (2017:66) Drynaria quercifolia life at a temperature of 28C-30C. According to Kurniawati et al (2016) Drynaria quercifolia live on the soil $\mathrm{pH}$ of $7.5-8$ soil moisture of $20 \%-40 \%$. Phymatosorus scolopendria life on the $\mathrm{pH}$ of the soil that is 7,09 while the soil moisture of $12 \%$ and live at an environmental temperature of 31C. According to riastuti has et al (2018) Phymatosorus scolopendria life on the $\mathrm{pH}$ of the soil was 6.18 and soil moisture of $20 \%-40 \%$.

Family Davalliaceae consists of 2 species, namely Davallia denticulate and Davallia solida. Davallia denticulate life on the $\mathrm{pH}$ of the soil 7,09 while the soil moisture of $13 \%$ and the temperature of the air around 33C. According to riastuti has et al (2018) Davallia denticulate life at a temperature of $28 \mathrm{C}-31 \mathrm{C}$ which means the temperature is relatively normal for the growth of nails. According to Kurniawati et al (2016), Davallia denticulate life on the $\mathrm{pH}$ of the soil is about 7.9-8 while the soil moisture reaches $20 \%-40 \%$.

Family Selaginella ceae as much as 2 species, namely Selaginella ceae plana and Selaginella ceae wildenowii. Selaginella plana life on the $\mathrm{pH}$ of the soil that is 7.08 to while soil moisture is $10 \%$ and the ambient temperature 32C. According to Apriyanti et al (2017) Selaginella plana life at an environmental temperature of 24C-32C. According to riastuti has et al (2018) live on the $\mathrm{pH}$ of the soil was 6.18 which means sour. While the soil moisture of $8.5 \%-9 \%$, which is wet (Permana, 2017).

Family Pteridaceae consisting of 1 species, namely Pteris biaurita. Pteris biaurita life on the $\mathrm{pH}$ of the soil that is 7.08 to while soil moisture $9 \%$ and the ambient temperature $32 \mathrm{C}$. According to riastuti has et al (2018) Pteris biaurita life at an environmental temperature of $28 \mathrm{C}-31 \mathrm{C}$ which means the temperature is relatively normal for the growth of the nails and the life on the soil pH 6,16 which means sour. the soil moisture of 1.5 alkaline (Sari, 2017).

Family Aspleniaceae have 1 species namely Asplenium nidus. Asplenium nidus was found in the $\mathrm{pH}$ of the soil 6,12 that is relatively normal (Permana, 2017). The temperature of the air around $31 \mathrm{C}$ which means the temperature is relatively normal for the growth of nails (riastuti has et al., 2018:58). The soil moisture of 13\%. According to Ridianingsih et al (2017) soil moisture on the ferns Asplenium nidus which is $20 \%$.

Family Gleicheniaceae have 1 species namely Gleichenia linearis life on the $\mathrm{pH}$ of the soil from 8.00 while the soil moisture $9 \%$ and the ambient temperature $31 \mathrm{C}$ which means the 
temperature is relatively normal for the growth of nails (riastuti has et al., 2018). According to Kurniawati et al (2016) Gleichenia linearis live on the soil $\mathrm{pH}$ of 7.5 , while the soil moisture of $20 \%-40 \%$. Gleichenia linearis have the branching that each branch of the two branches and each branch will be forked again. The roots are colored green and sporangium are of Pina (young leaves) and its spread limited along the leaves (Elsifa et al., 2019).

Family Lycopodiaceae have 1 species namely Lycopodium cernuum life on the $\mathrm{pH}$ of the soil 7,09 while soil moisture is $29 \%$ and the ambient temperature 32C. According to Syafrudin et al (2016) Lycopodium cernuum life on the ambient temperature ranges from 19C which means the temperature is relatively normal for the growth of pakuand soil moisture 90\%. Family Blechnaceae have 1 species namely Dyplazium pynocarpon life on the $\mathrm{pH}$ of the soil 7,09 while the soil moisture $9 \%$ and the air temperature was around 32C.

There are a few ferns (Pteridophyta) are only found, due to differences in environmental temperature, soil moisture, and soil $\mathrm{pH}$. Ferns (Pteridophyta) love the cool temperature and high humidity as well as the soil $\mathrm{pH}$ in the range 6-7. If the soil $\mathrm{pH}<7$ is acidic and if the soil $\mathrm{pH}>7$ is alkaline (Permana, 2017). Abiotic factors are influential for the growth of ferns (Pteridophyta), among others, the environmental temperature, soil moisture, soil $\mathrm{pH}$, light intensity, and altitude. Parameters measured in this study is the environmental temperature, soil pH and soil moisture. According to Permana (2017) stated that the influence of soil $\mathrm{pH}$ on the absorption of nutrients and growth includes the effect of toxic substances and humidity nutrients. Spikes that live in the area of rocky require a pH more alkaline ie 7-8. Most of the ferns (Pteridophyta) are found in the PT Bina Sains Cemerlang growing on fertile soil with alkaline $\mathrm{pH}$ between 7.08 to- 8,00 .

In addition to the factors of soil $\mathrm{pH}$ also there is a temperature plays a role in the growth of nails. Ferns (Pteridophyta) are grown in rubber Plantation PTPN Nusantara 3 Rantau Prapat grow with the range of temperature of 29C-32C. According to Permana (2017) stated that in the temperature range between 30C-33C not too many ferns (Pteridophyta).

In addition there is soil moisture. Imaniar et al (2017), states that the increasing height of the air temperature and humidity in the location of research is decreasing. The moisture level of 3\% is the lowest percentage that can still be tolerated by the ferns (Pteridophyta) for its growth. Relative humidity is good for the growth of ferns (Pteridophyta) generally ranges between 6-8\% can be even more than that. Soil moisture effect on nutrient absorption and growth rate (Permana, 2017).

Ferns (Pteridophyta) has a level of tolerance against certain environmental conditions in order to stay alive and thrive. If environmental conditions change exceeds the level of tolerance, it will result in the destruction of the vegetation of the habitat (Permana, 2017). Based on the results of the research.

The development of the ferns (Pteridophyta) prefers a soil $\mathrm{pH}$ that is alkaline, the temperature of the environment is relatively normal, and the soil moisture is relatively low. Although there are some spikes that can live in high temperature and soil moisture is relatively high, and low can be said that the types of ferns that can only be found in certain areas because it has a low tolerance to environmental conditions. 


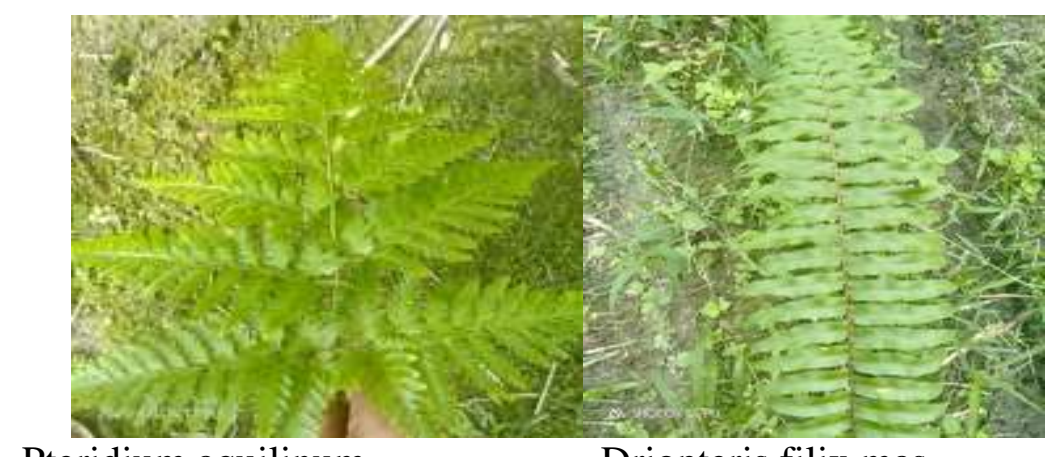

Pteridium aquilinum Driopteris filix mas

\section{Conclusion}

Based on the results of the study concluded that the ferns (Pteridophyta) that have been found in the rubber Plantation PTPN Nusantara 3 Rantau Prapat District Labuhanbatu ie 7 families and 17 species of Asplenium nidus, Dyplazium pynocarpon, Davallia denticulate, Davallia solida, Nephrolepis biserrata, Nephrolepis cordifolia, Nephrolepis exaltata, Nephrolepis sp., Ploecnemia irregularis, Stenochlaenae palustris, Gleichenia linearis, Lycopodium cernuum, Diplazium esculentum, Drymoglossum piloselloides, Drynaria quercifolia, Phymatosorus scolopendria, Pteris biaurita. Abiotic factors on the location of the research, namely the temperature of the air that is $29 \mathrm{C}-32 \mathrm{C}$ relatively normal, the humidity of the soil that is to $7.9 \%-69 \%$ is a good moisture for the growth of the nails, the $\mathrm{pH}$ of the soil ranges from an $8.08-8,90$ is alkaline.

\section{References}

Asbar. (2004). Jenis Paku-pakuan (Pteridophyta) di Sekitar Air Terjun Tirta Rimba Hutan Wana Osena Desa Sumber Sari Kecamatan Moramo District Konawe Selatan. Skripsi. Fakultas Keguruan dan Ilmu Pendidikan. Universitas Haluoleo.Kendari (Tidak diterbitkan).

Apriyanti,N.,Santri,D.J.,\&Madang,Kodri.(2017).IdentifikasiTumbuhan Paku (Pteridophyta) dan Kekerabatannya diKawasan Wisata Air Terjun Curup Tenang Bedegung Kecamatan Tanjung Agung District Muara Enim.JurnalPembelajaranBiologi.5(2),113125.

Arini, D.I.D., \& Julianus, J. (2012). Keragaman Jenis Tumbuhan Paku (Pteridophyta) DiCagarAlam Gunung Ambang Sulawesi Utara (ThePteridhopyta Diversity in Gunung Ambang Nature Reserve North Sulawesi). Jurnal BPK Manado, 2(1), 17-40.

Ceri, B., Lovadi, I., \& Linda, R. (2014). Keanekaragaman Jenis Paku-pakuan (Pteridophyta) di Mangrove Muara Sungai Peniti Kecamatan Segedong District Pontianak. Jurnal Protobiont, 3(2), 240-246.

Elsifa, A., Arisandy, A.D \& Harmoko. (2019). Eksplorasi Tumbuhan Paku (Pteridophyta) Di STL Ulu Terawas, Musi Rawas, Sumatera Selatan. BIOSFER: Jurnal Tadris Biologi, 10(1)47-55.

Fitriana, R. (2008). Mengenal Tumbuhan. Bandung: Putra Setia.

Steennis, Van C.G.G.J. (1988). Flora Untuk Sekolah di Indonesia. Terjemahan Moeso Surjowinoto. Edisi 7. Pradnya Paramita. Jakarta.

Tjitrosoepomo, G. 1994. Taksonomi Tumbuhan Obat-obatan. Gadjah Mada University Press. Yogyakarta 
Imaniar, R., Pujiastuti \& Murdiyah, S. (2017). Identifikasi Keanekaragaman Tumbuhan Pakudi Kawasan Air Terjun Kapas Biru Kecamatan Pronojiwo District Lumajang serta Pemanfaatannya sebagai Booklet. Jurnal Pendidikan Biologi, 6(3), 337-345.

Kurniawati, E., Wisantri \& Rachmadiarti, F. Keanekaragaman Pteridophyta di Kawasan Hutan Wisata Air Terjun Girimanik District Wonogiri. Jurnal Lentra Bio. 5(1), 74-78.

Mardiastutik, W. (2013).MengenalTumbuhan.Bekasi: Mitra Utama.

Purnawati, U., Turnip, M., \& Lovadi, I. (2014). Eksplorasi Paku-pakuan (Pteridophyta) di CagarAlam Mandor District Landak. Jurnal Protobiont, 3(2), 155-165.

Permana, N, E, P. (2017). Identifikasi keanekaragaman Divisi Pteridophyta (Paku) dikawasan Bukit Sulap Kota Lubuk linggau. Skripsi. Lubuk linggau: STKIP PGRI Lubuk linggau.

Riastuti, R.D., Sepriyaningsih, \& Ernawati, D. (2018). Identifikasi Divisi PteridophytaDi Kawasan Danau Aur District Musi Rawas. JurnalPendidikan Biologi dan Sains (BIOEDUSAINS), 1(1),52-70.

Ridianingsih, D.S., Pujiastuti, \& Hariani, S. A. (2017). Inventarisasi Tumbuhan Paku (Pteridophyta) dipos Rowobendo Ngagelan Taman Nasional Alas Purwo District Banyuwangi. Jurnal Bioeksperimen, 3 (2), 20-30.

Saktyowati, D.(2010). Mengenal Dunia Tumbuhan.Jakarta: Multazam Mulia Utama.

Sari, N.M. (2017). Identifikasi Keanekaragaman Divisi Pteridophyta (Paku) sebagai bahan pengembangan Booklet di kawasan Bukit Cogong District Musi Rawas.Skripsi.STKIPPGRI Lubuk linggau.

Steenis,C.G.G.J.Van.(2013).Flora.JakartaTimur:BalaiPustaka.

Syafrudin, Y., Haryati, T.S., \& Wiedarti, S. (2016). Keanekaragaman Dan Potensi Paku(Pteridophyta) Di Taman Nasional Gunung Gede Pangrango Cianjur (TNGGP).JurnalEkologia,16(2),24-31.

Tjitrosomo, S.S. (2010). Botani Umum 3. Bandung: Angkasa.Wijana,N.(2014).Biologidan Lingkungan.Yogyakarta:Plantaxia.

Zailani, M. et al. (2019). Growth Response and Crop Production (Brassica Juncea L.) Against Watering Time Interval at Various Hydroponics Media. Budapest International Research in Exact Sciences (BirEx) Journal. P. 9-22. 